Brit. J. industr. Med., 1961, 18, 153.

\title{
CEREBRAL TUMOUR IN A LEAD WORKER
}

\author{
BY \\ R. W. PORTAL
}

From the Central Middlesex Hospital

(RECEIVED FOR PUBLICATION AUgust 30, 1960)

\begin{abstract}
A case is reported in which a frontal astrocytoma occurring in a lead worker was initially misdiagnosed as lead encephalopathy. The evidence in favour of lead poisoning as a secondary diagnosis is discussed and details given of the urinary lead excretion in response to intravenous EDTA. It was concluded that though excess lead absorption had occurred, the history and findings were not such as to have made a diagnosis of lead encephalopathy tenable.
\end{abstract}

Industrial lead poisoning is becoming an uncommon event in this country and instances of lead encephalopathy are now very rare (Hunter, 1957). Many physicians therefore have scanty experience in diagnosing and investigating such cases, which tend to gravitate more and more to centres specializing in industrial diseases. They may not be familiar with the degree of exposure liable to lead to a dangerous level of lead absorption and may have difficulty in interpreting tests which suggest that absorption has occurred. This case is reported not in the hope that it will add anything of value to the literature of lead poisoning, but because it contains certain errors and misapprehensions which it is salutary to put on record. A mistake in diagnosis was made, and it may be of interest to recount the events as they occurred and then review them in the light of the more experienced advice later received.

\section{Case History}

A 63-year-old bullion refiner was admitted to hospital on January 1, 1960. He had been in good health up to the night of his admission and had experienced no metallic taste in his mouth, no constipation or colic, and no weakness of the limbs; his wife had observed nothing abnormal in his mental state. On December 31 , 1959 , at about 11.0 p.m. she found him unconscious in front of the television set. His limbs were stiff, his breathing heavy, and she was unable to rouse him. On arrival in hospital an hour later he was stuporose, irritable and incapable of speech. His left pupil was larger than his right, he did not move his left arm and his left plantar response was equivocal. There was no papilloedema. His blood pressure was $200 / 100 \mathrm{~mm}$. $\mathrm{Hg}(160 / 80 \mathrm{~mm}$. Hg two weeks later). The only other abnormal finding was a profuse crop of very small petechiae on the trunk and limbs which faded in the next day or two. He was edentulous. A lumbar puncture on admission produced clear cerebrospinal fluid (C.S.F.) containing protein 20 $\mathrm{mg} . / 100 \mathrm{ml}$., white blood cells $2 / \mathrm{c} . \mathrm{mm}$. and red blood cells $9 /$ c.mm. The cerebrospinal fluid Wassermann reaction was negative. He was too restless for a pressure reading to be taken.

By the following morning he was rational but amnesic for the period since the onset of the attack. All abnormal neurological signs had disappeared. During the next five days he had two more epileptiform attacks in which a transient left-sided weakness was noted. Between these he was at times confused. He was febrile from the second to the fifth day with a maximum temperature of $100.5^{\circ} \mathrm{F}$.

It was intended to investigate him routinely as a case of symptomatic epilepsy, but in view of his extensive petechiae a blood film was examined. This unexpectedly showed very coarse punctate basophilia with a stippled red cell count ranging from 6,000 to 12,000 per million red cells. His haemoglobin was $97 \%$ and white blood cells $9,000 /$ c.mm.; the platelets were reported as atypical. Chest radiograph, electrocardiogram, skull radiograph and electroencephalogram (E.E.G.) were normal. There was a slight proteinuria, the urine deposit containing epithelial cells only. Blood urea was $46 \mathrm{mg}$./ $100 \mathrm{ml}$. and $29 \mathrm{mg} . / 100 \mathrm{ml}$. six days later.

On questioning him about his occupation the following facts emerged. On leaving school he had served in the Navy as a signalman for seven years till 1920. He then worked for five years as a fitter in a company producing white lead, but he denied any contact with lead during this period. Since 1925 he had been employed by a London company refining precious metals and except for the war years had worked in the furnace rooms, where for the past few years he had been a charge-hand. Lead is regularly used in the refining process and the employees take precautions to minimize exposure. He thus wore a Martindale mask consisting of a wire frame with a muslin filter. He was normally conscientious about this, though he admits that he sometimes removed it for a smoke. 
TABLE 1

\begin{tabular}{cc|c|c|c}
\hline $\begin{array}{c}\text { Date } \\
(1960)\end{array}$ & $\begin{array}{c}\text { Amount of } \\
\text { EDTA } \\
\text { Infused } \\
\text { (g.) }\end{array}$ & $\begin{array}{c}\text { 24-hour Urinary } \\
\text { Excretion of } \\
\text { Lead } \\
\text { (mg.) }\end{array}$ & $\begin{array}{c}\text { Concentration } \\
\text { of Lead in } \\
\text { Urine } \\
\text { (mg./1.) }\end{array}$ \\
\hline Jan & 4 & 1 & $3 \cdot 78$ & 1.18 \\
Jan & 5 & - & 0.38 & 0.42 \\
Jan & 7 & 1 & 2.75 & 1.25 \\
Jan & 8 & 2 & 2.88 & 1.10 \\
Feb & 18 & 2 & 0.036 & 0.02 \\
Feb & 19 & 2 & 2.22 & 1.0 \\
Feb 20 & 2 & 1.45 & 0.72 \\
\hline
\end{tabular}

On December 22 and 23 (a week before the onset of symptoms), and again on December 28 , he was one of a number of men given the special task of transferring by shovel some 12 tons of litharge $(\mathrm{PbO})$ from bins into steel drums. This material consisted of greyishyellow lumps and powder, the moving of which inevitably raised a certain amount of dust. At the time of this operation he was suffering from a head cold; he was also a heavy smoker who rolled his own cigarettes. He suffered no ill effects, however, while carrying out the work. The employees' urine is tested at intervals for porphyrins, and on looking up the patient's record it was found that the tests had been positive for some time past.

His history of exposure to lead and the coarse stippling of his red cells suggested that his symptoms were due to lead poisoning and that we were dealing with a case of lead encephalopathy. Owing to the three days' delay in diagnosis and the recurrence of fits it was decided to start treatment without undertaking a preliminary control estimation of urinary lead excretion and without pursuing further investigations such as cerebral angiography. On January 4, therefore, an intravenous infusion of $1 \mathrm{~g}$. ethylenediamine tetra-acetate (EDTA, disodium calcium versenate) was administered in $500 \mathrm{ml}$. of dextrose solution. A 24-hour urine collection started synchronously with the infusion contained a total of $3.78 \mathrm{mg}$. of lead in $3,200 \mathrm{ml}$. of urine. The amount of lead in the blood 18 hours after the infusion was $190 \mathrm{mg} . / 100 \mathrm{ml}$. The ensuing 24-hour excretion of lead (when no EDTA was given) was $0.38 \mathrm{mg}$. On January 7 a further gramme of EDTA was infused, and three more doses of $2 \mathrm{~g}$. followed in the next four days. The urinary lead outputs on January 7 and 8 were $2.75 \mathrm{mg}$. and $2.88 \mathrm{mg}$. respectively. A further course of EDTA totalling $9 \mathrm{~g}$. was given in five daily infusions from January 18 to 23 , but lead excretion was not measured. The patient was discharged in apparent good health 23 days after admission.

When readmitted on February 18 for further excretion studies his resting 24-hour urinary lead output was $0.036 \mathrm{mg}$.; three more daily infusions of EDTA were given, which on the first two days resulted in a rise of lead excretion to $2.22 \mathrm{mg}$. and $1.45 \mathrm{mg}$. The results of the various estimations are set out in Table 1 .

We assumed at this point that the tissue lead concentration had been reduced to a safe level and no further treatment with EDTA was given. The patient's last fit had occurred on January 6 , a week after the onset of symptoms, and his mental state had become normal the next day. He appeared perfectly well and was already back at work where his employment had been changed to avoid any further exposure to lead.

Early in April a message was received from his factory indicating that all was not well. He had been complaining of headache, had unaccountably put on over a stone in weight, and his workmates had noticed that he had lost his usual cheerfulness and was becoming slow and unreliable. Indeed his behaviour during the preceding few days had been so unlike him that he was considered unfit for work. He was readmitted on April 16.

It did not take long to make a diagnosis : reinvestigation showed that he was suffering from a cerebral tumour. The personality change was obvious; he was rational and orientated but ponderous and apathetic. He had a partial left facial palsy and hemiparesis. His C.S.F. now contained $140 \mathrm{mg}$. of protein at a pressure of $250 \mathrm{~mm}$.; the E.E.G. had become abnormal and indicated a space-occupying lesion in the right fronto-temporal area. Finally carotid angiography (not carried out on his original admission) revealed pathological vessels in the right frontal region with displacement of the right anterior cerebral artery to the left.

He declined rapidly and died four weeks after admission (five months after the convulsion which was his first symptom). At necropsy a large irregular primary tumour with a necrotic centre was found in the right frontal lobe, extending backwards into the parietal lobe. There was no other macroscopic abnormality in the brain and other organs were normal. Histologically the tumour was a fibrillary astrocytoma. Routine preparations from the rest of the brain showed no evidence of nerve cell damage. Microscopy of the kidneys, which to the naked eye were normal, revealed some tubular damage, with variability of the nuclei of the epithelial cells, some cytoplasmic degeneration, and an occasional mitotic figure indicative of regeneration. The damage thus displayed was by no means specific but could be attributed to lead poisoning. The bone structure of femur and vertebrae was normal. Estimations of the lead content of various tissues are given in Table 2.

TABLE 2

LEAD CONTENT OF TISSUES

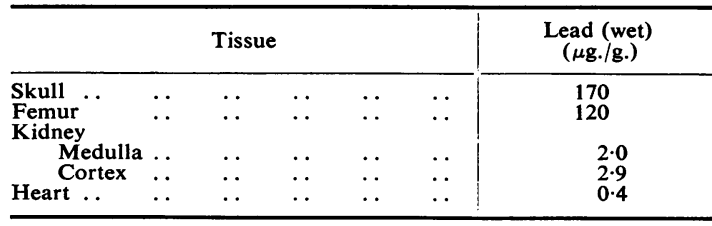

\section{Discussion}

The patient was at first notified to the Inspector of Factories as a case of industrial lead poisoning. The most significant fact in his history was the recent shovelling of litharge. This is well known among lead workers to be a dangerous substance, and the Martindale mask which he was wearing 
could be considered inadequate protection for the task. The sudden increase in absorbed lead resulting from these three days' unduly heavy exposure was presumed to be the final insult superimposed on a background of slow chronic absorption. The work was heavier than he was accustomed to, and the increased pulmonary ventilation involved was well calculated to give ingress to a fine dusty form of a soluble lead oxide. He was in addition a heavy smoker who rolled his cigarettes; inhalation of lead transferred from his fingers to the tobacco was another possible source of undue absorption. He was furthermore suffering from a cold at the time, and intercurrent infections are recognized as enhancing the toxic effects of lead. That his body lead content was already raised was indicated by the positive urinary porphyrin tests recorded in the factory. The high output of lead in the urine in response to EDTA (maximum $3.78 \mathrm{mg} . / 24 \mathrm{hrs}$; normal $0.22-0.65 \mathrm{mg}$.) again suggested lead poisoning as a possible diagnosis. Still more support was lent by his immediate improvement after treatment with EDTA, as judged by the disappearance of mental confusion and the cessation of fits.

Despite its rarity in adults lead encephalopathy remains a condition to bear in mind when neurological symptoms develop in a person known to have been exposed to lead. Clinically it may present in a wide variety of ways. Danaraj (1956), for example, reported four cases presenting initially as encephalitis, dementia paralytica (GPI), coma, and an obscure neurological disorder. Three of of these were adults and one a boy of 11 ; all of them had a raised C.S.F. protein, three had an excess of lymphccytes in the C.S.F. and three had a raised C.S.F. pressure. Akelaitis (1941) emphasized that the clinical picture was that of any severe intoxication of the brain, with its resulting delirium or convulsions. The predominant pathological change was oedema of the brain, probably resulting from vascular damage; exudate was seen in the perivascular spaces, the meninges were oedematous and thickened, and proliferative changes were found in the endothelial cells of the small blood vessels (Akelaitis, 1941; Blackman, 1937).

There have been many accounts of the use of EDTA in lead poisoning since Bessman, Ried, and Rubin (1952) first employed it successfully on a 3-year-old boy with lead encephalopathy. Treatment in the present case was carried out on the lines indicated by Leckie and Tompsett (1958) who undertook investigations on eight wire mill workers, seven of whom had been exposed to lead. They found that increasing the dose of EDTA above $2 \mathrm{~g}$. did not significantly raise the urinary lead excretion, and that the duration of the infusion was of im- portance in achieving a good output. They suggested an infusion period of six hours, or continuous slow infusion over 48 hours in severe cases. Excessive absorption of lead was indicated by a 24-hour lead output of more than $1.5 \mathrm{mg}$. in response to $2 \mathrm{~g}$. of EDTA; in control subjects the excretion lay between 0.22 and $0.65 \mathrm{mg}$. (compare $3.78 \mathrm{mg}$./ 24 hours in the present patient). A fall in excretion below $1.5 \mathrm{mg}$. in the second 24 hours of any course of infusions suggested that the available lead stores were becoming depleted.

The lead content of the patient's bones was at the upper limit of the range found in normal subjects without undue exposure to lead, and probably well beyond it. Estimates for long bones vary from less than $3.8 \mu \mathrm{g}$. per gramme wet tissue to $108 \mu \mathrm{g}$. (Cumings, 1959). The patient's levels furthermore compare well with values found in known sufferers from lead encephalopathy in whom long bone concentrations ranging from 8.5 to $176 \mu \mathrm{g}$. per gramme wet tissue have been reported ( $C f$. Cumings). This patient moreover had received three courses of EDTA and it can be assumed that the untreated level would have been higher.

When the cerebral neoplasm was discovered the notification of industrial lead poisoning was withdrawn. In discussing the case later this retraction was criticized on the grounds that the man had after all suffered excess lead absorption as shown by the coarse red cell stippling, high urinary lead excretion and the raised bone lead content, and that his original fit might have been triggered off by a sudden increase of lead in brain or blood. According to this view he might have stood to claim under the Industrial Injuries Acts. The cancellation was defended, on the other hand, by pointing out that the entire clinical picture could be explained by the tumour alone, and that this, in any case, was what killed him. One could not assert that the clinical course would have been any different had there been no exposure to lead at all.

There are indeed certain facts which weigh against the diagnosis of lead encephalopathy and which, had we been more familiar with the subject, would have dissuaded us from postulating this as the cause of the man's symptoms. Though he had worked for 35 years in contact with lead, he was engaged in a process in which the lead hazard was not a serious one. He was therefore, a 'salted' worker, who had not hitherto proved himself susceptible to lead poisoning. The fact that his urinary porphyrin tests were positive is not evidence of a dangerous level of lead absorption. Raised coproporphyrin figures are usual in lead workers and in the absence of quantitative tests a positive 
result is of no great value in determining the degree of absorption in any given case. His good health up to the time of the fit, the absence of any symptoms attributable to chronic lead absorption, and in particular his haemoglobin of $97 \%$, should have cautioned us against too ready a diagnosis of lead intoxication, especially its rare manifestation of encephalopathy. A raised punctate count is seen in many lead workers and was particularly likely to occur in someone recently exposed to the lead oxide of litharge dust. It was the coarseness of the stippling, coupled with what was interpreted as a significant history of exposure, that first led to the pursuit of a red herring and the diagnosis of a rare condition rather than a commoner and more probable one. The conclusion is that though excess absorption had occurred the patient was not suffering from lead poisoning, and all his symptoms were attributable to the neoplasm.

Finally, it is of interest to recall that lead compounds have been used with some enthusiasm as cytotoxic agents in cancer therapy. Professor Blair Bell (1930), the Liverpool gynaecologist, undertook the treatment of a wide variety of malignant neoplasms on a.considerable scale (566 patients between 1920 and 1928), and claimed successful results in $21 \%$ of those who were thought to have had adequate treatment. Organic lead salts were given intravenously at weekly intervals, each injection containing some $25 \mathrm{mg}$. lead. Primary cerebral growths, however, were not among those recorded as receiving this treatment. One can only speculate whether an increased concentration of lead in the brain would render a patient with a coexisting neoplasm more liable to epilepsy; but in view of the known cytotoxic properties of lead it would be most unlikely to accelerate the growth of the tumour.

The lead estimations were kindly undertaken by Dr. Donald Hunter and Dr. George Kazantzis in the Department for Research in Industrial Medicine, the London Hospital. (Method employed: $\mathrm{HNO}_{3}-\mathrm{HClO}_{4}$ ashing; dithizone; monocolour.)

I thank Dr. Richard Asher for permission to publish this report, and Professor R. E. Lane and Dr. T. O. Garland for their very valuable guidance and criticisms.

\section{REFERENCES}

Akelaitis, A, J (1941), J. nerv, ment, Dis, $93,313$. Bell, W. Blair (1930). Some Aspects of the Cancer Problem. Baillière, Tindall and Cox, London.

Bessman, S. P., Ried, H., and Rubin, M. (1952). Med. Ann. Distr. Columbia, 21, 312 .

Blackman, S. S. (1937). Bull. Johns Hopk. Hosp., 61, 1.

Cumings, J. N. (1959). Heavy Metals and the Brain. Blackwel Scientific Publications, Oxford.

Danaraj, W. (1956). Proc. Alumni Ass. Malaya, 9, 107

Hunter, Donald (1957). The Diseases of Occupations, 2nd ed. English Universities Press, London.

Leckie, W. J. H., and Tompsett, S. L. (1958). Quart. J. Med. (n.s.), 